\title{
Impact of COVID-19 on Brazilian women in teleworking
}

\author{
Cláudia Aparecida Avelar Ferreira* \\ Camila Álvares dos Reis ${ }^{\star *}$
}

The COVID-19 pandemic had an impact on the personal, professional, and academic routines of female Brazilian teleworkers. This study aims to analyze the impact of teleworking on the lives of Brazilian women amid the pandemic. The method was a quantitative and exploratory approach, and an online cross-sectional survey conducted with 478 women. The results showed a positive correlation between academic routines and teleworking ( $p<0.05 ; r>0.00)$ and a significant association between emotional health and academic routines ( $p<0.001)$. Black women were shown to expend more effort toward academic activities than White women ( $p<0.044)$. The study results contribute to the social sciences by demonstrating the impact of COVID-19 on Brazilian women in teleworking and indicate potential implications for policy formulation and public management in Brazil.

Keywords: Teleworking. Triple workload. Personal, academic, and professional routines.

\footnotetext{
* Pontifícia Universidade Católica de Minas Gerais (PUC Minas), Belo Horizonte, Brazil (claudiahgv@gmail.com; http://orcid.org/0000-0002-8802-1716).

** Pontifícia Universidade Católica de Minas Gerais (PUC Minas), Belo Horizonte, Brazil (cammi.reis@gmail.com; http://orcid.org/0000-0002-0532-1132).
} 


\section{Introduction}

Worldwide, the COVID-19 pandemic brought about several challenges; in Brazil, it significantly impacted the labor market, causing a net loss of 1.4 million jobs from March to June 2020. After this loss, from July to October 2020, 1.1 million jobs were created, but 300,000 jobs are yet to be recovered, according to the Economic Commission for Latin America and the Caribbean (CEPAL, 2021).

This global health crisis highlighted the centrality of people's life assistance and working conditions, especially among paid female homemakers (VALENZUELA; SCURO, 2020). Undurraga and Hornickel (2021) emphasized that the pandemic exacerbated vulnerabilities of women in Chile, generating visible impacts in various spheres of their lives, such as decreased mental health, increased violence, overloaded care services, and reduced participation in the labor market. Moreover, they pointed out that patriarchy is visible in companies and that the main issue for women relates to the conciliation between work and family. However, these women reported feeling extremely affected by high workloads and lack of rest, as well as perceiving losses regarding psychosocial well-being.

Social inequality has increased and the most vulnerable groups in Peru, such as less qualified people, women and youngsters, migrants, refugees and independent workers have felt the negative effects. This occurs because they do not have the means to prevent loss of income, given the difficulties to access transfer or income stimulus programs (GAMERO; PÉREZ, 2020). Farné and Sanín (2021) show that women were most affected by the pandemic in Colombia, as $52 \%$ of them lost their jobs, and that the chance of getting a job in the short term is low, which increased the commitment to domestic routines and care for family members heading into retirement from the labor market. Cardoso and González (2020) demonstrated that in Argentina, gender inequalities are also significant and persistent in the labor market.

In the context of COVID-19, the so-called "new normal" was characterized by the mandated closure of various companies, with those that needed to remain operative forced to adapt their environments to the pandemic (PAIVA REIS et al., 2020). Many professionals were required to work from home; specifically, some sectors (e.g., the information and communication technology sector) adopted this as the only option to remain productive and active during the pandemic. From March to December 2020, when several lockdowns were imposed by the Brazilian government (MENDES, 2020), work-from-home contracts were established for all professionals who were able to adapt accordingly. However, there are important and clear gender differences in the context of these lockdowns and working from home, motivated by several historical factors, such as racial and economic inequalities, as remnants of slavery and gender inequalities in Brazil, which also influenced the late entry of women into the labor market (PIMENTA, 2020).

This caused many Brazilian women to resort to homemaking roles either for survival or to comply with their social function in a patriarchal society. According to the United Nations 
(UN Women, 2020), women have a high burden of homemaking tasks due to the need to deal with home and family care. Before the pandemic, women already spent a daily average of three hours doing unpaid housework, while men only spent one hour; in the pandemic scenario, this condition has worsened (UN Women, 2020).

This scenario begs the question: what impact did the pandemic have on the personal, professional, and academic routines of Brazilian female teleworkers? To respond to this question, this study aimed to analyze the impact of teleworking on Brazilian women's lives amid the COVID-19 pandemic. The study covers a gap in social science literature by demonstrating the impact of COVID-19 on Brazilian women in teleworking and points out potential implications for policy formulation and public management in Brazil.

\section{Background}

The effects of the COVID-19 pandemic led to economic collapse in several countries (GUO et al., 2020) and impacted people's lives. Although teleworking has been adopted in some sectors, those that could not make this transition have affected the economy, especially in large urban centers.

Ceribeli and Rocha (2019) emphasized the ambivalence of workers regarding teleworking, showing that those who can balance their personal and professional routines become less exhausted and have greater job satisfaction, but are not more productive than those who cannot. Barros and Silva (2010) pointed out that presenteeism can be a threat to physical and mental health, since it can lead to illness, which may subsequently lead to decreased quality of life owing to work-related factors. However, as Garrett and Danziger (2007) pointed out, information and communication technology did not cause companies to shift to teleworking, as there are several factors that can lead professionals or other workers to make this shift, such as organizational policies and individual choices. In addition, they categorized teleworking into three types - fixed, mobile, and flexible - and described the following four teleworking dimensions: job location, information and communication technology, time distribution, and contract type between worker and employer.

Teleworking has its advantages and disadvantages (BARROS; SILVA, 2010; CERIBELI; ROCHA, 2019), and the characteristics of this type of work have affected women's lives and careers, owing to personal, organizational, and social mechanisms (O'NEIL, 2003; O'NEIL; BILIMORIA, 2005; LOMBARDI, 2006; MOREIRA et al., 2018). Among these mechanisms are the balance between personal and professional life and job satisfaction (GREENHAUS et al., 2003), the double workload related to employment and housework (BERLATO; CORRÊA, 2017), and the triple workload related to employment, maternity/family, and education/ training. Moreover, studies have shown that some major issues related to the management of teleworking for employees relate to work qualifications (ALMEIDA; MOTA-SANTOS, 2018; VIEIRA; AMARAL, 2013) and feelings regarding the distribution of time and energy 
between professional and personal life (KIRCHMEYER, 2000) and between work and nonwork (SCANFONE et al., 2008).

França and Schimanski (2009) emphasized that women face difficulties when adjusting to home and work demands. During the pandemic, many women were highly likely to have needed to increase their daily work time even further; specifically, in addition to household chores (e.g., preparing food, cleaning, taking care of hygiene, washing clothes, shopping), they also had to care for their children and adolescents, deal with children's school tasks, and care for elderly people and sick family members, before finally engaging in their own individual activities. Thus, there was a forced change in the modus operandi of people's routines, resulting in the need to expend greater effort when conducting daily tasks under this new dynamic (WOLFF et al., 2020).

Several studies have analyzed different variables related to female teleworkers, such as domestic violence (RETTBERG, 2020; VIEIRA et al., 2020), job loss or resignation (BURKI, 2020), scholarship cuts (WOLFF et al., 2020), professional relationships (BARROS; SILVA, 2010; MENEZES, AMORIM, 2020; DUARTE et al., 2020), social inequity (PIMENTA, 2020), morbidity and mortality rates of Black women (CHANDLER et al., 2021), and impacts on academia (GABSTER et al., 2020) and leisure (MAYOR et al., 2020). These studies have especially focused on women with children and those who are students, married, or unmarried. However, there seems to be a lack of studies in Latin America about female teleworkers from the perspective of gender amid a public health crisis such as the COVID-19 pandemic.

According to Bonelli and Marinho (2020), in this scenario, greater attention should be paid to women with school-aged children, because their children are more likely to face difficulties when absorbing content, due to remote education. Another impact on women's personal lives is the higher probability of developing mental disorders (e.g., anxiety and depression) compared with men, which may be due to genetic, hormonal, or inequality conditions. These conditions can be accentuated by the pandemic through increased violence, abuse, and discrimination during social isolation (DUARTE et al., 2020). On the issue of mental health, Lizote et al. (2021) described the importance of well-being (emotional, professional, and social) and autonomy for employees in teleworking because it can help teleworkers avoid various illnesses and promote satisfaction.

Braga et al. (2019) identified that women's achievements within the scope of work are characterized by precarious work, power relations inequality, gender inequality, and division of work by gender, which promote the extension of their family-related activities and lead to double and triple workloads. Singh and Pattanaik (2020) presented a critique on women working in the private domain, namely homemaking, emphasizing that although homemaking activities are often unpaid, they are essential and highly productive for families and the economy. Hence, despite such positive outcomes related to this unpaid work, it brings forth the stereotype of the women as homemakers, which renders them invisible to society. Further, the pandemic also worsened racial inequality in the Brazilian context 
(GARCIA, 2020; SANTOS et al., 2020), which led to women becoming more burdened with childcare, work, and in some cases, educational or academic tasks (VIEIRA; AMARAL 2013; BERLATO; CORRÊA, 2017; ALMEIDA; MOTA-SANTOS, 2018). All these factors have been shown to potentially affect women's mental health (UNDURRAGA; HORNICKEL, 2021).

The pandemic, and the subsequent move to teleworking, caused changes in women's lives, bringing about difficulties of various orders. In many cases, these women were already engaging in daily double or triple workloads. Agenjo-Calderón (2021) criticized the invisibility of women, arguing that they should instead be subjects of study and of a separate discipline, as this may allow for them to break from subordination and have voices that question the androcentric economy.

To analyze the phenomenon of teleworking in Brazilian women and the routines of those engaging in double and triple workloads, the following hypotheses (Chart 1) and question were raised: what impacts have women experienced from this pandemic in terms of personal, professional, and academic routine in telework?

\section{CHART 1}

Study hypotheses

\begin{tabular}{|cl|}
\hline Hypotheses & \multicolumn{1}{c|}{ Description } \\
\hline H1 & Women's professional routines are influenced by the teleworking model. \\
H2 & There is a positive relationship between teleworking and greater dedication to work. \\
H3 & There is a negative relationship between the number of children and women's personal \\
H4 & Age and a higher number of children affect teleworking in women. \\
H5 & There is a positive relationship between personal routine and academic routine. \\
H6 & There is a negative relationship between teleworking and academic routine by race. \\
H7 & Among Black and White women, skin color positively and differently influences academic \\
H8 & routines.
\end{tabular}

\section{Methods}

This was an exploratory, quantitative, cross-sectional study (CRESWELL, 2009). In the questionnaire used in the present study, for race, the classifications set forth by the Statute of Racial Equality (BRASIL, 2010) and the Brazilian Institute of Geography and Statistics (IBGE, 2014) were used, which consider the racial identity of Black (Black and brown skin color) and White women, excluding "yellow" and indigenous racial identities. In Brazil, prejudice against the Black population is of note (NOGUEIRA, 2006), because the more prominent differences in physical appearance and skin color, the more discrimination they face owing to the structural racism that is present in the country (GONZALEZ, 2018), a parameter that is also reflected in the presence of Black people in different social classes (MARIANO; CARLOTO, 2009). 
The data from this survey came from people living in different cities in Brazil. The data were collected during the COVID-19 pandemic, between November 24 and 30, 2020, from a non-probabilistic sample. The questionnaire was developed using Google Forms and made available on a variety of online social media platforms including the researchers' social media pages; the posts asked Brazilian women to respond to the questionnaire and/or share it on their social media profiles. That is, a snowball sampling technique was used (VINUTO, 2014). The inclusion criteria were Brazilian women (cis or trans) who had completed at least nine years of schooling, while the exclusion criteria where those who identified as men. Ethical procedures related to anonymity comprised the elimination of data related to the participants' names and email addresses from the forms, thus ensuring confidentiality.

To assess only women, we used a survey developed by the researchers themselves (2020), called "Of women to women survey." This self-report the women comprises 5 subscales and 18 items: personal routines ( 8 items), professional routines ( 3 items), academic routines ( 3 items), teleworking ( 4 items), and demographic variables (12 items). Each item $(20,21,22,23)$ is scored on Likert-type scale that ranges from 1 (extremely unfavorable) to 5 (extremely favorable) (JAMIESON, 2004). Scores were calculated by adding the scores in each item. Higher scores indicated greater power. This is demonstrated in hypothesis testing, which usually focuses on power, defined as the probability of rejecting $\mathrm{H} 0$ when it is false (i.e., power $=1-\beta=\mathrm{P}$; reject $\mathrm{H} 0 \mid \mathrm{H} 0$ is false). Potency is the probability that a test correctly rejects a false null hypothesis. An ideal test is one with low probability of making a Type I error (i.e., small a) and high power (i.e., small $\beta$ ). The Alpha (a) refers to type I error is rejecting the null hypothesis in favorable a false alternative hypothesis and Beta $(\beta)$ is type II error that rejects the false null hypothesis in favor of a true alternative hypothesis (WEISS, 2016).

The remaining questions were categorical. Cronbach's a for the original tool was $>0.60$ for exploratory research (HAIR et al., 2009); in this study, $a \geq 0.60$ except to professional routine, but the Kaiser-Meyer-Olkin (KMO) value was 0.50 . Cronbach's a represents the proportion of the total variance of the scale that is attributed to the true score of the latent construct being measured, and it should be greater than 0.70 to indicate construct reliability. In exploratory research, values above 0.60 are also accepted. In addition, the KMO value verifies the proportion of variance of data that can be considered common to all variables. The values of this measure vary between 0 and 1 , and the use of factor analysis is adequate for the data when the KMO value is greater than or equal to 0.50 ; the closer to 1 , the more appropriate the sample is for the application of factor analysis (MINGOTI, 2007).

\section{Statistical analysis}

In total, 479 participants responded to the questionnaire. However, since one respondent was a foreigner, her data were disregarded. The data were evaluated by 3 
characterization variables, and 22 items of the questionnaire were related to 4 first-order constructs and 1 second-order construct. Of the 10,516 answers to the 22 questions usable and 8 subtracted, contained in the bank about the constructs, 186 blank or meaningless answers were found. To deal with these missing data, they were treated with a mean imputation method based on prior research, as it is considered one of the most appropriate methods and has been widely used (HAIR et al., 2009). These data were maintained in the descriptive exploratory analysis, corresponding to Q9, 11, 17, 18, and 22. Hence, the descriptive exploratory analysis did not utilize all questionnaire data from the 478 women.

Figure 1 shows the Brazilian states that were included in the study. To construct this image, the world tool from art.com was used, with the "cloud" filter applied. The larger the letters in the cloud, the greater the representativeness of the women in the corresponding state who participated in the study. The state of Minas Gerais stands out, and in relation to region, $74 \%, 9 \%$, and $8 \%$ of the participants were from southeastern, northeastern, and midwestern Brazil, respectively.

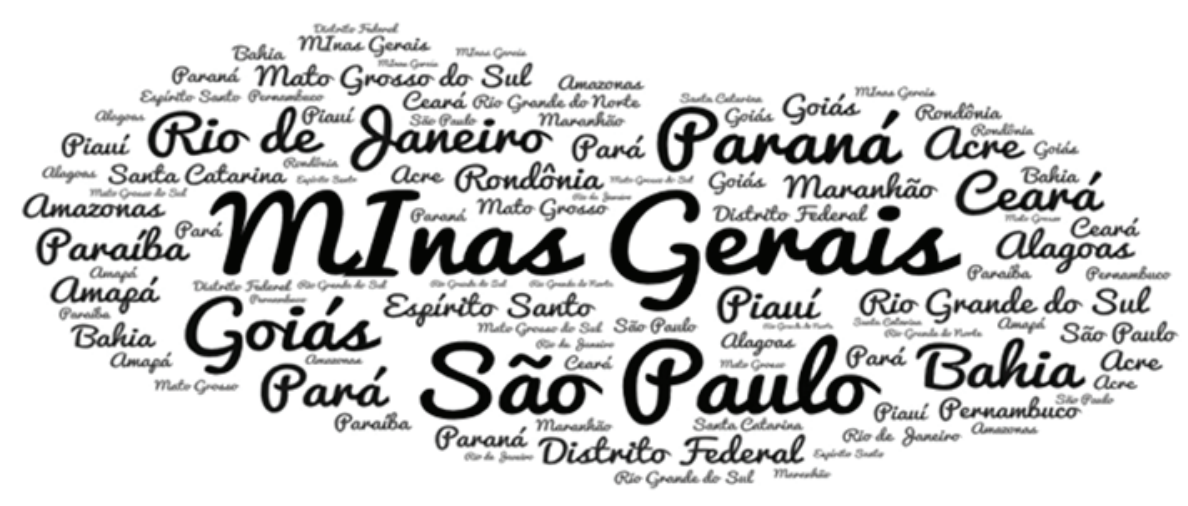

Source: The authors.

In the descriptive analysis, the characterization variables, and the items of the builders (routines) were used as absolute and relative frequencies. To verify the relationships between the questions, chi-square testing (AGRESTI; KATERI, 2011) was conducted at the level of $5 \%$ significance.

To decide which indicators would be used to represent the constructs in the questionnaire, we employed factor analysis, and the dimensionality of the constructs was verified through the criterion for parallel lines (HOYLE; DUVALL, 2004), which also serves to describe the number of dimensions of the construct. The quality of the indicators derived through the factor analysis was evaluated through convergent validity and reliability analyses for each construct. 
For evaluating convergent validity, we used average variance extracted (AVE) (FORNELL; LARCKER, 1981), which represents the average percentage of variance shared between the latent construct and its items. Based on prior research, AVE values above 50\% (HENSELER et al., 2009), or $40 \%$ in the case of exploratory research (NUNNALLY; BERNSTEIN, 1994), denote appropriate convergent validity. To evaluate reliability, we used Cronbach's a and composite reliability (CR) (CHIN, 1998) as indicators. According to Tenenhaus et al. (2005), construct reliability is secured upon Cronbach's a and CR valued above 0.70 , or values above 0.60 in the case of exploratory surveys (HAIR et al., 2009).

The Kruskal-Wallis test (HOLLANDER; WOLFE, 1999) was used to compare the variables that characterized the first- and second-order constructs. For multiple comparisons, we employed the Nemenyi test (HOLLANDER; WOLFE, 1999), and to verify the correlation between the indicators and the ordinal variables, we used Spearman's correlation coefficient (HOLLANDER; WOLFE, 1999). This coefficient is limited between -1 and 1, and the closer the coefficient is to -1 , the higher the negative correlation; the closer the coefficient is to 1 , the higher the positive correlation.

We used double or triple workloads and teleworking as the dependent variables, while the independent variables were routines: personal, professional, and academic. $R$ (version 4.0.3) was used for analyses, and variables were described by a confidence interval of $95 \%$.

\section{Results}

\section{Factor analysis}

During factor analysis, the following items presented a factor load below 0.50 , and were thereby removed from the questionnaire: items Q13, Q22, Q23, Q26, Q27, and Q30 on personal routine; item Q19 on professional routine; and item Q7 on academic routine. Table 1 presents the factor loads of eliminated items. According to Hair et al. (2009), items with factor loadings smaller than 0.50 should be eliminated from the constructs because they do not contribute in a relevant way to the formation of the latent variable, impairing the reach of the basic assumptions for the validity and quality of the indicators created. In the descriptive analysis for the characterization variables and the items of the constructs, we used absolute and relative frequencies.

The values for the measures of the validity and quality of the first-order constructs are described in Table 2. All constructs presented convergent validity (i.e., AVE > 0.40) and proper reliability (i.e., a Cronbach's a and/or CR above 0.60 ) and were deemed as appropriate for the application of factor analysis (i.e., $K M O \geq 0.50$ ). Based on the criterion of parallel lines, the constructs were deemed as one-dimensional. 
TABLE 1

Factor analysis of the first-order constructs

\begin{tabular}{|c|c|c|c|c|c|c|c|}
\hline \multirow[b]{2}{*}{ Constructs } & \multirow[b]{2}{*}{ Items } & \multicolumn{3}{|c|}{ Initial model } & \multicolumn{3}{|c|}{ Final model } \\
\hline & & $\begin{array}{c}\text { Factor } \\
\text { loading }\end{array}$ & Commonality & Weight & $\begin{array}{l}\text { Factor } \\
\text { loading }\end{array}$ & Commonality & Weight \\
\hline \multirow{8}{*}{ Personal routine } & Q13 & 0.21 & 0.04 & 0.12 & & & \\
\hline & Q14 & 0.61 & 0.37 & 0.34 & 0.92 & 0.84 & 0.55 \\
\hline & Q16 & 0.66 & 0.43 & 0.37 & 0.92 & 0.84 & 0.55 \\
\hline & Q22 & 0.30 & 0.09 & 0.17 & & & \\
\hline & Q23 & 0.56 & 0.31 & 0.31 & & & \\
\hline & Q26 & 0.39 & 0.15 & 0.22 & & & \\
\hline & Q27 & 0.44 & 0.19 & 0.25 & & & \\
\hline & Q30 & 0.43 & 0.18 & 0.24 & & & \\
\hline \multirow{3}{*}{$\begin{array}{l}\text { Professional } \\
\text { routine }\end{array}$} & Q10 & 0.73 & 0.53 & 0.64 & 0.75 & 0.57 & 0.66 \\
\hline & Q12 & 0.73 & 0.54 & 0.64 & 0.75 & 0.57 & 0.66 \\
\hline & Q19 & -0.26 & 0.07 & -0.23 & & & \\
\hline \multirow{3}{*}{$\begin{array}{l}\text { Academic } \\
\text { routine }\end{array}$} & Q7 & -0.05 & 0.00 & -0.03 & & & \\
\hline & Q24 & 0.86 & 0.74 & 0.58 & 0.86 & 0.74 & 0.58 \\
\hline & Q29 & 0.86 & 0.74 & 0.58 & 0.86 & 0.74 & 0.58 \\
\hline \multirow{4}{*}{ Teleworking } & Q20 & 0.73 & 0.53 & 0.38 & 0.73 & 0.53 & 0.38 \\
\hline & Q21 & 0.78 & 0.62 & 0.41 & 0.78 & 0.62 & 0.41 \\
\hline & Q25 & 0.69 & 0.48 & 0.36 & 0.69 & 0.48 & 0.36 \\
\hline & Q28 & 0.53 & 0.28 & 0.28 & 0.53 & 0.28 & 0.28 \\
\hline
\end{tabular}

Source: Search data.

TABLE 2

Quality criteria of the first-order constructs

\begin{tabular}{lcccccc}
\hline \multicolumn{1}{c}{ Constructs } & Items & AVE (1) & CA (2) & CR (3) & KMO (4) & Dim. (5) \\
\hline Personal routine & 2 & 0.84 & 0.80 & 0.85 & 0.50 & 1 \\
Professional routine & 2 & 0.57 & 0.20 & 0.62 & 0.50 & 1 \\
Academic routine & 2 & 0.74 & 0.65 & 0.77 & 0.50 & 1 \\
Teleworking & 4 & 0.48 & 0.61 & 0.71 & 0.69 & 1 \\
\hline
\end{tabular}

Source: Search data.

(1) Average extracted variance; (2) Cronbach's Alpha; (3) Composite Reliability; (4) Kaiser-Meyer-Olkin value, or adequacy of the sample; (5) Dimensionality.

Table 3 shows the factor analysis results for the second-order construct of effort and its indicators; the indicators of personal routine and professional routine presented a factor loading below 0.50 in the initial model and were therefore removed. The second-order construct effort uses to assess of alternative measure model that can describe the data. This is necessary when there are multiple measurement model configurations that can characterize a given data set (KOUFTEROS; BABBAR; KAIGHOBADI, 2009). 
TABLE 3

Factor analysis of the second-order construct and its indicators

\begin{tabular}{|c|c|c|c|c|c|c|c|}
\hline \multirow[b]{2}{*}{ Construct } & \multirow[b]{2}{*}{ Indicators } & \multicolumn{3}{|c|}{ Initial model } & \multicolumn{3}{|c|}{ Final model } \\
\hline & & $\begin{array}{c}\text { Factor } \\
\text { loading }\end{array}$ & Commonality & Weight & $\begin{array}{c}\text { Factor } \\
\text { loading }\end{array}$ & Commonality & Weight \\
\hline \multirow{4}{*}{ Effort } & Personal routine & 0.19 & 0.04 & 0.11 & & & \\
\hline & $\begin{array}{l}\text { Professional } \\
\text { routine }\end{array}$ & -0.29 & 0.08 & -0.17 & & & \\
\hline & Academic routine & 0.89 & 0.80 & 0.51 & 0.92 & 0.84 & 0.54 \\
\hline & Teleworking & 0.91 & 0.83 & 0.52 & 0.92 & 0.84 & 0.54 \\
\hline
\end{tabular}

Source: Research data.

Table 4 presents the values for the measures of validity and quality of the secondorder construct. The construct presented convergent validity (i.e., AVE > 0.40) and proper reliability (i.e., a Cronbach's a and/or CR above 0.60 ) and was deemed as appropriate for the application of factor analysis (i.e., $\mathrm{KMO}=0.50$ ). Based on the criterion of parallel lines, the construct was deemed as one-dimensional.

TABLE 4

Validation of the second-order construct

\begin{tabular}{ccccccc}
\hline Construct & Items & AVE (1) & CA (2) & CR (3) & KMO (4) & Dim. (5) \\
\hline Effort & 2 & 0.84 & 0.79 & 0.86 & 0.50 & 1 \\
\hline
\end{tabular}

Source: Search data.

(1) Average extracted variance; (2) Cronbach's Alpha; (3) Composite reliability; (4) Kaiser-Meyer-Olkin value, or adequacy of the sample; (5) Dimensionality.

Table 5 provides a description of the second-order indicator, effort, based on first-order indicators. The mean score for effort was 3.3, with a standard deviation of 1.11, the 1 st and 3rd quartiles were 2.43 and 4.33 , respectively. Namely, $25 \%$ of participants had a score equal to or less than 2.43 and $75 \%$ had a score equal to or less than 4.33 .

TABLE 5

Description of the participants' results for the second-order indicator

\begin{tabular}{ccccccccc}
\hline Construct & N & Mean & SD & Minimum & 10Q & 20Q & 30Q & Maximum \\
\hline Effort & 478 & 3.30 & 1.11 & 1.00 & 2.43 & 3.45 & 4.33 & 5.00 \\
\hline
\end{tabular}

Source: Search data.

Note: SD - standard deviation; Minimum - lowest value; Q - quartile; Maximum - highest value.

\section{Participant characteristics}

A descriptive analysis of the categorization variables showed that most participants were between 25 and 30 years old (49.37\%), had no children (64.15\%), Black $(50.42 \%)$, unmarried (48.54\%), and had reasonable help for household chores (58.11\%). Most women with children (66.39\%) did not assist or teach with regard to school activities. Most perceived that the pandemic altered their routine $(72.38 \%$ ) and pointed out that their relationships with family members were also altered by spending longer periods at home 
(54.18\%). Most respondents expressed that, at least at some point, they felt depressed for no specific reason (89.12\%).

Regarding conciliation, $37.03 \%$ of participants partially agreed that it is possible to conciliate their personal, professional, and academic routines and teleworking. However, most $(89.12 \%)$ had already lost their patience at home with their children or family, at work, or in their studies. Moreover, over half of those who were married (64.85\%) maintained their relationships even after teleworking. However, most participants $(78.87 \%)$ were not able to maintain their leisure activities after becoming teleworkers.

Professional routines and teleworking corresponded to $60.8 \%$ of participants' routines. The largest proportion of participants attended law school (30.13\%), and $61.92 \%$ of participants reported having an increased workload after becoming teleworkers. Nevertheless, their productivity and relationships within the work context remained unchanged after becoming teleworkers (42.3\%). Regarding their academic routine, most attended a post-graduate course $(55.44 \%)$, while $52.09 \%$ lost their initial motivation to study and be productive upon becoming teleworkers. Moreover, almost half (48.95\%) of the participants thought that their academic productivity would be lower if the pandemic continued, and they remained working under complete or partial teleworking conditions.

Regarding the relationship between teleworking and academic routine, $24.69 \%$ agreed that several changes brought on by the pandemic were positive, although $24.9 \%$ disagreed that their teleworking routine was more productive, while $16.11 \%$ agreed that it was more productive than their regular routines. About half of the women $(50.21 \%)$ were unable to conciliate their personal, professional, and academic routines while teleworking, and $72.38 \%$ perceived something positive regarding their personal, professional, or academic routine experiences related to teleworking amid the pandemic.

\section{Participant scores for the indicators in the questionnaire and variable correlations}

Table 6 presents the relationships between the first-order constructs based on the factor analysis. Hence, study participants tended to experience greater effort related to their professional routines and lower effort related to their personal routines.

TABLE 6

Description of the first-order indicators

\begin{tabular}{lcccccccc}
\hline \multicolumn{1}{c}{ Construct } & N & Mean & SD & Minimum & $\mathbf{1}^{\mathbf{0}} \mathbf{Q}$ & $\mathbf{2}^{\mathbf{0}} \mathbf{Q}$ & 3ㅇ $^{\mathbf{0}}$ & Maximum \\
\hline Personal routine & 478 & 2.35 & 1.64 & 1.00 & 1.00 & 1.50 & 3.00 & 5.00 \\
Professional routine & 478 & 3.82 & 1.18 & 1.00 & 3.00 & 4.00 & 5.00 & 5.00 \\
Academic routine & 478 & 3.54 & 1.40 & 1.00 & 2.00 & 4.00 & 5.00 & 5.00 \\
Teleworking & 478 & 3.07 & 1.01 & 1.00 & 2.30 & 3.11 & 3.92 & 5.00 \\
\hline
\end{tabular}

Source: Search data.

Note: SD - standard deviation; Minimum - lowest value; Q - quartile; Maximum - highest value. 
Indicators were compared by race to verify whether race had a negative influence on Black participants'telework routines. Table 7 shows a comparison of the scores for these indicators by race, with no significant difference ( $p$ > 0.05) between the indicators.

TABLE 7

Comparisons of the indicator scores by race (White and Black)

\begin{tabular}{|c|c|c|c|c|c|c|c|c|}
\hline Indicators & Race & $\mathrm{N}$ & Mean & EP & $1 \stackrel{0}{Q}$ & $2^{\circ} Q$ & $3 \div Q$ & P-value \\
\hline \multirow{2}{*}{ Personal routine } & White & 237 & 2.30 & 0.10 & 1.00 & 1.50 & 3.00 & \multirow{2}{*}{0.731} \\
\hline & Black & 241 & 2.39 & 0.11 & 1.00 & 1.50 & 5.00 & \\
\hline \multirow{2}{*}{$\begin{array}{l}\text { Professional } \\
\text { routine }\end{array}$} & White & 237 & 3.83 & 0.07 & 3.00 & 4.00 & 5.00 & \multirow{2}{*}{0.812} \\
\hline & Black & 241 & 3.80 & 0,08 & 3,00 & 4,00 & 5,00 & \\
\hline \multirow{2}{*}{ Academic routine } & White & 237 & 3,41 & 0.10 & 2.00 & 3.00 & 5.00 & \multirow{2}{*}{0.092} \\
\hline & Black & 241 & 3,66 & 0.08 & 3.00 & 4.00 & 5.00 & \\
\hline \multirow{2}{*}{ Teleworking } & White & 237 & 3.00 & 0.07 & 2.13 & 2.94 & 3.90 & \multirow{2}{*}{0.155} \\
\hline & Black & 241 & 3.13 & 0.06 & 2.34 & 3.14 & 3.93 & \\
\hline \multirow{2}{*}{ Effort measure } & White & 237 & 3.21 & 0.08 & 2.27 & 3.25 & 4.33 & \multirow{2}{*}{0.108} \\
\hline & Black & 241 & 3.40 & 0.07 & 2.57 & 3.55 & 4.33 & \\
\hline
\end{tabular}

Source: Search data.

Note: Mann - Whitney U test.

As studies have shown that darker skin color leads to higher levels of discrimination in Brazil, we divided non-white participants into two groups: Black and Brown. Table 8 shows a comparison of the results for the indicators by race. There was a significant difference $(p=0.044)$ between skin color and academic routine. The Nemenyi test showed a significant difference between Black and White participants; specifically, Black women tended to experience greater effort regarding their academic routines than their White counterparts.

TABLE 8

Comparisons of participant scores for each indicator by race and skin color

\begin{tabular}{|c|c|c|c|c|c|c|c|c|}
\hline Indicators & Race & $\mathbf{N}$ & Mean & EP & $10 Q$ & $2 \div Q$ & $3 \div Q$ & P-value \\
\hline \multirow{3}{*}{ Personal routine } & White & 237 & 2.30 & 0.10 & 1.00 & 1.50 & 3.00 & \multirow{3}{*}{0.578} \\
\hline & Brown & 124 & 2.46 & 0.15 & 1.00 & 1.50 & 5.00 & \\
\hline & Black & 117 & 2.32 & 0.16 & 1.00 & 1.50 & 5.00 & \\
\hline \multirow{3}{*}{$\begin{array}{l}\text { Professional } \\
\text { routine }\end{array}$} & White & 237 & 3.83 & 0.07 & 3.00 & 4.00 & 5.00 & \multirow{3}{*}{0.347} \\
\hline & Brown & 124 & 3.71 & 0.11 & 3.00 & 4.00 & 5.00 & \\
\hline & Black & 117 & 3.91 & 0.12 & 3.00 & 4.00 & 5.00 & \\
\hline \multirow{3}{*}{ Academic routine } & White & 237 & 3.41 & 0.10 & 2.00 & 3.00 & 5.00 & \multirow{3}{*}{0.044} \\
\hline & Brown & 124 & 3.50 & 0.12 & 2.00 & 4.00 & 5.00 & \\
\hline & Black & 117 & 3.84 & 0.11 & 3.00 & 4.00 & 5.00 & \\
\hline \multirow{3}{*}{ Teleworking } & White & 237 & 3.00 & 0.07 & 2.13 & 2.94 & 3.90 & \multirow{3}{*}{0.184} \\
\hline & Brown & 124 & 3.06 & 0.08 & 2.32 & 3.14 & 3.69 & \\
\hline & Black & 117 & 3.21 & 0.09 & 2.59 & 3.14 & 3.95 & \\
\hline \multirow{3}{*}{ Effort } & White & 237 & 3.21 & 0.08 & 2.27 & 3.25 & 4.33 & \multirow{3}{*}{0,058} \\
\hline & Brown & 124 & 3.28 & 0.09 & 2.43 & 3.32 & 4.20 & \\
\hline & Black & 117 & 3.53 & 0.09 & 2.80 & 3.79 & 4.33 & \\
\hline
\end{tabular}

Source: Search data.

Note: Kruskal-Wallis test. 
TABLE 9

Correlations between the questionnaire indicators and participant characteristics

\begin{tabular}{lcccccc}
\hline \multicolumn{1}{c}{ Factor } & $\begin{array}{c}\text { Personal } \\
\text { routine }\end{array}$ & $\begin{array}{c}\text { Professional } \\
\text { routine }\end{array}$ & $\begin{array}{c}\text { Academic } \\
\text { routine }\end{array}$ & Teleworking & Effort & Age \\
\hline $\begin{array}{l}\text { Professional } \\
\text { routine }\end{array}$ & $-0.01(0.770)$ & & & & & \\
Academic & $0.08(0.024)$ & $-0.06(0.208)$ & & & & \\
routine & $0.02(0.293)$ & $-0.18(0.000)$ & $0.69(0.000)$ & & & \\
$\begin{array}{l}\text { Teleworking } \\
\text { Effort }\end{array}$ & $0.06(0.058)$ & $-0.13(0.013)$ & $0.93(0.000)$ & $0.90(0.000)$ & & \\
Age & $0.36(0.000)$ & $0.09(0.069)$ & $-0.08(0,016)$ & $-0.09(0.044)$ & $-0.10(0.015)$ & \\
$\begin{array}{l}\text { Number of } \\
\text { children }\end{array}$ & $0.86(0.000)$ & $0.01(0.196)$ & $0.05(0,640)$ & $0.00(0.566)$ & $0.03(0.973)$ & $0.49(0.000)$ \\
\hline
\end{tabular}

Source: Search data.

Note: Values in parentheses are the p-values of each correlation.

Regarding the indicators, personal routine was significantly ( $p<0.050)$ positively $(r>0)$ correlated with academic routine. Professional routine was significantly $(p<0.050)$ negatively $(r<0)$ correlated with teleworking and effort, the higher the scores for professional routine, the lower the scores for teleworking and effort. Academic routine was significantly $(p<0.050)$ positively $(r>0)$ correlated with teleworking and effort, the higher the scores for academic routine, the higher the scores for teleworking and effort. Teleworking was significantly $(p<0.050)$ positively $(r>0)$ correlated with effort, the higher the score for teleworking, the higher the effort.

There was a significant positive $(r=0.36)$ correlation $(p<0.001)$ between age and personal routine, the greater the age, the higher the score for personal routine. There was also a significant negative $(r<0)$ correlation ( $p<0.050)$ among age and academic routine, teleworking, and effort, the higher the age, the lower the scores for academic routine, teleworking, and effort. There was a significant positive $(r=0.86)$ correlation $(p<0.001)$ between number of children and personal routine, the greater the number of children, the higher the score for personal routine. Finally, there was a significant positive $(r=0.49)$ correlation $(p<0.001)$ between age and number of children, the higher the age, the greater the number of children.

As in the descriptive data, $89.12 \%$ of the women reported experiencing depression; however, there was no statistical correlation with motivation ( $p>0.05$ ) between academic routines and depression. We sought to evaluate women's mental health regarding depression in relation to family relationships; the separation of personal, professional, and academic life; marital relationship and leisure activities. Accordingly, simulated chisquare and chi-square tests were performed.

Regarding the relationship between the academic routine and emotional health of the participants, motivation was not significantly associated ( $p>0.05)$ with the academic situation. There were significant associations $(p=0.014)$ between emotional health and family routine, emotional health and personal and professional routines, and emotional health and leisure $(p=0.008)$, based on the results for simulated chi-square and only chisquare tests for academic routines separately $(p<0.001)$ and emotional health. 


\section{Discussion}

The main points developed in this section refer to the personal, professional, academic routines and mental health of women in telework and the type of career most prevalent within this group, based on motherhood and race.

In our study, most women (89.12\%) reported that, at some point, they felt depressed for no specific reason; however, their emotional health did positively correlate with an inability to separate their academic routines $(p<0.001)$ and teleworking and between emotional health and personal routine $(p=0.014)$. These results are in line with previous research (UNDURRAGA; HORNICKEL, 2021; WANG et al., 2020; DUARTE et al., 2020; LIZOTE et al., 2020) and confirmed $\mathrm{H} 8$ (The women that are studying and telework have an impact on mental health). Lemos et al. (2020) stated that depression may be due to family work. These results indicate the consequences of the triple workload, or possibly the fourth workload (providing care to older or ill people), during the pandemic. Son et al. (2020) investigated the mental health and well-being of students in higher education and identified anxiety and stress as having a negative impact on academic performance. Wang et al. (2020) noted that it is the duty of the government to protect the psychological well-being of the population, and there is a need for intervention by the government and health agencies, which corroborated the findings of Son et al. (2020).

In our findings, personal routine correlated with academic routine $(p=0.024 ; r=0.07$; Table 9); hence, the higher the family demand, the greater the difficulties women experience in fulfilling academic tasks. This demonstrates that a triple workload can impact women's careers, a finding widely described in the literature (BRAGA et al., 2019; ALMEIDA; MOTA-SANTOS, 2018; BERLATO; CORRÊA, 2017; VIEIRA; AMARAL, 2013).

Indeed, a previous study showed that women tend to have less rest time when they do not have help at home in caring for their children, which results in work overload that affects their physical and mental health (UNDURRAGA; HORNICKEL, 2021). Moreover, our findings showed that older women who have more children $(p<0.001 ; r=0.47)$ tend to strive harder to fulfill their personal tasks, which can also impact their professional routine in teleworking, confirming $\mathrm{H} 4$ (Age and a higher number of children affect teleworking in women). These data also showed that teleworking correlates with more dedication to work, confirming $\mathrm{H} 2$ (There is a positive relationship between teleworking and greater dedication to work). Schieman et al. (2021) pointed out that having children between 6 and 12 years of age increases the level of work-life conflict $(b=0.099, p<0.05 ; b=0.244, p<0.001)$. The results also showed that the higher the number of children $(p<0.001 ; r=0.85$; Table 9), the higher the interferences in women's personal routine, hence refuting $\mathrm{H} 3$ (There is a negative relationship between the number of children and women's personal routines).

Further, our results showed that professional routines can be impacted by teleworking $(p<0.050 ; r<0)$, in that the higher the demand in the profession, the lower the dedication to teleworking (Table 9). On this regard, a previous study showed that non-conciliation 
between personal and work routines leads to overload for women, as does non-conciliation with childcare, which further leads to a potential downfall in productivity during teleworking (BARROS; SILVA, 2010). Therefore, such a lack of conciliation is a disadvantage for women, and our results confirmed $\mathrm{H} 1$ (Women's professional routines are influenced by the teleworking model). Since most of the study participants were single and did not have children, their productivity in teleworking did not seem to drecrease. This may be explained by past research, which shows that even with a double or triple workload (FRANÇA; SCHIMANSKI, 2009), teleworking still becomes advantageous for women (CERIBELI; ROCK, 2019).

The academic routines of women in our sample were correlated with telework; thus, the greater the academic demands, the greater the dedication to telework $(p\langle 0.050 ; r\rangle$ 0.00; Table 9). This shows that teleworking may impact women's results when attending university (GABSTER et al., 2020). Based on prior research (GARCIA, 2020), we can consider that with a double or triple workload and reduced time, the consequences will be lower participation in academic production, which confirms $\mathrm{H} 5$ (There is a positive relationship between personal routine and academic routine), especially for Black women.

Additionally, there was no significant influence of race on the independent variables (Table 7). However, when further categorizing participants by skin color (Table 8), our results showed that Black women, who are often more vulnerable, expended more effort toward academic activities than White women ( $\mathrm{c}$ 0.044), a result that corroborates past literature (PIMENTA, 2020; SANTOS, 2020). This result also served to confirm H7 (Among Black and White women, skin color positively and differently influences academic routines) and refute $\mathrm{H} 6$ (There is a negative relationship between teleworking and academic routine by race). Women with children and Black women submit fewer manuscripts $\left(x^{2}=91.01, p<0.0001\right)$ compared to men and women without children (STANISCUASK et al., 2020).

The literature shows that during the COVID-19 pandemic, women with children have mostly sought to improve their professional qualifications and engaged in triple workloads (BRAGA et al., 2019; ALMEIDA; MOTA-SANTOS, 2018; BERLATO; CORRÊA, 2017; VIEIRA; AMARAL, 2013), findings that are corroborated by our results. Thus, women who are already undertaking a triple work workload amid the COVID-19 pandemic should not engage in a potential fourth workload. This can be accomplished, for example, with the inclusion of substitute teachers for remote education, thereby avoiding the potential greater negative impact on their careers and academic work, which can harm their mental health.

This study's findings point to the complexity of women's lives during the pandemic in relation to telework and the impacts on personal, professional, and academic routines, and provide both a warning regarding racial and social inequality and likely implications for policy action and public management in Brazil. 


\section{Conclusion}

This study analyzed the impact of telework on Brazilian women's lives amid the COVID-19 pandemic. Women in our sample perceived that the pandemic evoked changes in their routine $(72.38 \%)$ and in their relationships with family members $(54.18 \%)$, and most reported feeling depressed at some point for no specific reason (89.12\%). Additionally, $37.04 \%$ of the women reported that they were able to conciliate their teleworking and their personal, professional, and academic routines, while $89.12 \%$ reported having already lost their patience with either their children or family or in their work or academic lives. Among those married in our sample, most (64.85\%) reported that they retained their relationship status, although most $(78.87 \%)$ failed to maintain leisure activities.

In our sample, Black women, who are often more vulnerable, expended more effort to academic activities than White women ( $p<0.044)$. These results also showed that the higher the number of children ( $<<0.001 ; r=0.85)$, the higher the interference in women's personal routines. Regarding the relationship between telework and academia, $24.69 \%$ agreed that the COVID-19 pandemic brought about positive changes; $50.21 \%$ reported not being able to conciliate their teleworking with their personal, professional, and academic routines; and $72.38 \%$ perceived that the pandemic brought something positive to their personal, professional, or academic lives. Hypotheses 1, 2, 3, 4, 5, 7, and 8 were confirmed, while hypothesis 6 was refuted. The results showed that there was a positive correlation between academic routines and teleworking ( $p<0.05 ; r>0.00)$ and significant associations between emotional health and academic routines separately $(p<0.001)$.

The lack of conciliation between different routines in women's lives during the pandemic may compromise their mental health and teleworking productivity. However, in our sample, many women perceived positive changes in their lives related to the COVID-19 pandemic, and some reported feeling positive toward telework despite not being able to conciliate their personal, professional, and academic routines.

\section{Limitations and suggestions for future research}

The inference that our results yielded about older women having more children and the impact that having more children has on personal tasks and teleworking can lead to a limitation on occupation. Therefore, this hypothesis should be better analyzed in the future by other research approaches, such as qualitative methods. It is noteworthy that these findings could also impact $\mathrm{H} 2$, because teleworking was correlated with more dedication to work. Hence, future studies should analyze the professional and personal routines of this population in the scenario of the COVID-19 pandemic, such as whether women had to leave work due to the burden of household duties or stopped looking for work/rejected some job offers due to an overload of household duties. 
One limitation of our study was the format of the questionnaire, which should have included all items except those on demographic characteristics rated using Likert-type scales. Thus, it was impossible to use structural modeling and identify which variable moderated or mediated relationships that described an enhanced teleworking performance in our sample. In addition, the study presented a regionalization of work due to most women belonging in the southeastern region. The women were not asked whether they lived in an urban or rural area. Moreover, there were several blank and incomplete questions, which may have interfered with the study findings; thus, it is important to leave all mandatory issues on survey. Additionally, our sample did not include transwomen or other ethnic groups.

\section{References}

AGENJO-CALDERÓN, A. Genealogía del pensamiento económico feminista: las mujeres como sujeto epistemológico y como objeto de estudio en economía. Revista de Estudios Sociales, n. 75, p. 42-54, 2021. Available at: https://doi.org/10.7440/res75.2021.05.

AGRESTI, A.; KATERI, M. Categorical data analysis. Gainesville, Florida: John Wiley, 2011.

ALMEIDA, V. C.; MOTA-SANTOS, C. M. Work, career and motherhood: the outlooks and dilemmas of contemporary women professionals. Administração: ensino e pesquisa (RAEP), v. 19, n. 3, p. 1-15, 2018. Available at: https://doi.org/10.13058/raep.2018.v19n3.1119.

BARROS, A. M.; SILVA, J. G. Individuals perceptions about the consequences of telework in the home-office configuration: a case study at Shell Brazil. Cadernos EBAPE.BR, v. 8, n. 1, p. 71-91, 2010. Available at: https://doi.org/10.1590/S1679-39512010000100006.

BERLATO, H.; CORRÊA, K. F. A reformulation of the dual career conceptual model for analysis in an organizational scope: revealing new aspects. BBR - Brazilian Business Review, v. 14, n. 2, p. 225-246, 2017. Available at: https://doi.org/10.15728/bbr.2017.14.2.5.

BONELLI, M. G.; MARINHO, R. Gender, professions and home office during the pandemic. Contemporânea, Revista de Sociologia da UFSCar, v. 10, n. 1, p. 443-455, 2020.

BRAGA, N. L.; ARAUJO, N. M.; MACIEL, R. H. Work conditions of women: an integrative review of the Brazilian literature. Psicologia: Teoria e Prática, v. 21, n. 2, p. 232-251, 2019. Available at: http://dx.doi.org/10.5935/1980-6906/psicologia.v21n2p232-251.

BRASIL. Presidência da República. Lei n. 12.288 de 20 de julho de 2010. Estatuto da Igualdade Racial destinado a garantir à população negra a efetivação da igualdade de oportunidades, a defesa dos direitos étnicos individuais, coletivos e difusos e o combate à discriminação e às demais formas de intolerância étnica. Diário Oficial da União, Brasília, 21 jul. 2010.

BURKI, T. The indirect impact of COVID-19 on women. The Lancet Infection Disease, v. 20, n. 8 , p. 904-905, 2020. Available at: https:// doi.org/ 10.1016/S1473-3099(20)30568-5.

CARDOZO, G.; GONZALEZ, A. S. Trajetórias de trabalho de mulheres de setores populares em transição para a vida adulta. Ciencias Psicologicas, Montevidéu, v. 14, n. 2, e2210, 2020. Available at: http://dx.doi.org/10.22235/cp.v14i2.2210.

CEPAL - Comisión Económica para América Latina y el Caribe. Balance preliminar de las economías de América Latina y el Caribe, 2020. Santiago del Chile: Naciones Unidas, 2021. Available at: https://www.cepal.org/es/publicaciones/46501-balance-preliminar-economiasamerica-latina-caribe-2020. 
CERIBELI, H. B.; ROCHA, G. B. S. An analysis of the relationship between flexible work, emotional exhaustion and engagement of workers. Revista Ciências Administrativas, v. 25, n. 1, p. 1-14, 2019. Available at: https://doi.org./10.5020/2318-0722.2019.7420.

CHANDLER, R. et al. The impact of COVID-19 among Black women: evaluating perspectives and sources of information. Ethnicity and Health, v. 26, n. 1, p. 80-93, 2021. Available at: https:// doi.org/ 10.1080/13557858.2020.1841120.

CHIN, W. W. The partial least squares approach to structural equation modeling. In: MARCOULIDES, G. A. Modern methods for business research. 1st. ed. Mahwah, NJ, US: Lawrence Erlbaum Associates Publishers, 1998. p. 295-336.

CRESWELL, J. W. Research design: qualitative, quantitative, and mixed methods approaches. Thousand Oaks, Califórnia: Sage, 2009.

DUARTE, M. Q.; SANTO, M. A. S.; LIMA, C. P. L.; GIORDANI, J. P.; TRENTINI, C. M. Covid-19 and the impacts on mental health: a sample from Rio Grande do Sul, Brazil. Ciência \& Saúde Coletiva, v. 25, n. 9, p. 3401-3411, 2020. Available at: https://doi.org/10.1590/1413-81232020259.16472020.

FARNÉ, S.; SANÍN, C. Impacto de la COVID-19 sobre el mercado de trabajo colombiano y recomendaciones para la reactivación económica. Colombia: OIT / Oficina de la OIT para los Países Andinos, 2021. Available at: https://www.ilo.org/wcmsp5/groups/public/---americas/--ro-lima/---sro-lima/documents/publication/wcms_775897.pdf.

FORNELL, C.; LARCKER, D. F. Evaluating structural equation models with unobservable variables and measurement error. Journal of Marketing Research, v. 18, n. 1, p. 39-50, 1981. Available at: https://doi.org/10.2307/3151312.

FRANÇA, A. L.; SCHIMANSKI, É. Women, work and family: analysing feminine work and its consequences to family affairs. Emancipação, v. 9, n. 1, p. 65-78, 2009. Available at: http:// www.uepg.br/emancipacao.

GABSTER, B. P.; DAALEN, K.; DHATT ROOPA, M. B. Challenges for the female academic during the COVID-19 pandemic. The Lancet, n. 395, p. 1968-69. Available at: https://doi.org/10.1016/ S0140-6736(20)31377-5.

GAMERO, J.; PÉREZ, J. Peru - Impacto de la COVID-19 en el empleo y los ingresos laborales. Nota técnica país - Panorama laboral en tiempos de la COVID-19. Organización Internacional del Trabajo. ilo.org/americas, septiembre 2020.

GARCIA, L. P. Dimensiones del sexo, género y raza en la investigación sobre COVID-19. Epidemiologia e Serviços de Saúde, v. 29, n. 3, 2020. Available at: https://dx.doi.org/10.5123/s167949742020000300023.

GARRETT, K. R.; DANZIGER, J. N. Which telework? Defining and testing a taxonomy of technology mediated work at a distance. Social Science Computer Review, v. 25, n. 1, p. 27-47, 2007. Available at: https://dx.doi:10.1177/0894439306293819.

GONZALEZ, L. Primavera para as rosas negras. São Paulo: UCPA Editora, 2018.

GREENHAUS, J. H.; COLLINS, K. M.; SHAW, J. D. The relation between work-family balance and quality of life. Journal of Vocational Behavior, v. 63, n. 3, p. 510-31, 2003. Available at: https:// doi.org/ doi:10.1016/S0001-8791(02)00042-8.

GUO, Y. R. et al. The origin, transmission, and clinical therapies on coronavirus disease 2019 (COVID-19) outbreak - an update on the status. Military Medical Research, v. 7, n. 11, p. 1-10, 2020. Available at: https://doi.org/10.1186/s40779-020-00240-0. 
HAIR, J. F.; BLACK, W. C.; BABIN, B. J.; ANDERSON, R. E.; TATHAM, R. L. et al. Análise Multivariada de Dados. Porto Alegre: Bookman, 2009.

HENSELER, J.; RINGLE, C. M.; SINKOVICS, R. The use of partial least squares path modeling in international marketing. Advances in International Marketing, v. 20, p. 277-319, 2009. Available at: https:/doi.org/10.1108/S1474-7979(2009)0000020014.

HOLLANDER, M. D. A.; WOLFE, E. C. Nonparametric statistical methods. New York: John Wiley \& Sons, 1999.

HOYLE, R. H.; DUVALL, J. L. Determining the number of factors in exploratory and confirmatory factor analysis. In: KAPLAN, D. (ed.). The Sage handbook of quantitative methodology for the social sciences. Thousand Oaks, CA: Sage, 2004.

IBGE - Instituto Brasileiro de Geografia e Estatística. Estatísticas de gênero: uma análise dos resultados do censo demográfico 2010. Estudos \& Pesquisas, v. 33, 2014.

JAMIESON, S. Likert scales: how to (ab)use them. Medical Education, v. 38, n. 12, p. 1217-8, 2004. Available at: https://doi.org/10.1111/j.1365-2929.2004.02012.x.

KIRCHMEYER, C. Work-life initiatives: greed or benevolence regarding workers time. In: COOPER, C. L.; ROUSSEAU, D. M. (ed.). Trends in organizational behavior. West Sussex: Wiley, v. 7, 2000. p. 79-93. Available at: https://doi.org/10.1515/kbo-2018-0119.

KOUFTEROS, X.; BABBAR, S.; KAIGHOBADI, M. A paradigm for examining second-order factor models employing structural equation modeling. International Journal of Production Economics, v. 120, p.633-652, April 2009.

LEMOS, A. H. C.; BARBOSA, A. O.; MONZATO, P. P. Mulheres em home office durante a pandemia da Covid-19 e as configurações do conflito trabalho-família. Revista de Administração de EmpresasRAC, São Paulo, v. 60, n. 6, p. 388-399, dez. 2020. Available at: http://dx.doi.org/10.1590/ s0034-759020200603.

LIZOTE, S. A.; TESTON, S. F. T.; RÉGIS, E. S. O.; MONTEIRO, W. L. S. Pandemic times: subjective well-being and autonomy in home office. RGO - Revista Gestão Organizacional, v. 14, n. 1, p. 248-268, 2021. Available at: http://dx.doi.org/10.22277/rgo.v14i1.

LOMBARDI, M. R. Engineer and manager: challenges to women in managerial positions in technological areas. Revista Tecnologia e Sociedade, v. 2, n. 3, p. 63-86, 2006. Available at: https://www.redalyc.org/articulo.oa?id=496650322005.

MARIANO, S. A.; CARLOTO, C. M. Gender and poverty fight: the family donation program. Revista de Estudos Feministas, v. 17, n. 3, p. 901-908, 2009. Available at: https://doi.org/10.1590/ S0104-026X2009000300018.

MAYOR, S. T. S.; SILVA, M. S.; LOPES, C. G. Perspectives about women's leisure with the new coronavírus pandemic: reflections based on the research data leisure in Brazil- representations and concretizations of everyday experiences. Licere, v. 23, n. 3, p. 163-189, 2020. Available at: https://doi.org/10.35699/2447-6218.2020.25363.

MCGOVERN, N.; CROXFORD, R. 100 women 2020: who is on the list this year? BBC 100 Women, 30 november 2020. Available at: https://www.bbc.com/news/world-55042935.

MENDES, A. Covid-19: Ministério da Saúde define critérios de distanciamento social. Brasília: Agência Saúde, Ministério da Saúde, 2020.

MENEZES, J. B.; AMORIM, A. M. A. The impacts of Covid-19 on family law and the fracture of dialogue and empathy. Civilistica.com, v. 9, n. 2, p. 1-38, 2020. Available at: https://civilistica. emnuvens.com.br/redc/article/view/517. 
MINGOTI, S. A. Análise de dados através de métodos de estatística multivariada: uma abordagem aplicada. Belo Horizonte: Editora UFMG, 2005.

MOREIRA, M. G.; SILVA, A. H.; GOMES, M. E. R. Percepção de sucesso na carreira: um estudo com docentes de universidades federais do Rio Grande do Sul. Pretexto, v. 19, n. 3, p. 63-80, jul./set. 2018. Available at: https://doi.org/10.21714/pretexto.v19i3.4762.

NOGUEIRA, O. Mark and origin: a framework for the analysis of racial prejudice in Brazil. Tempo Social, v. 19, n. 1, p. 287-308, 2006. Available at: https://doi.org/10.1590/S010320702007000100015.

NUNNALLY, J. C.; BERNSTEIN, I. H. Psychometric theory. 3rd. New York: McGraw-Hill, 1994.

ONU MULHERES. Coronavirus and gender: more chores for women set back gains in equality. BBC 100 Women Published, 26 November 2020. Available at: https://www.bbc.com/news/ world-55016842.

O’NEIL, D. A. Working in context: understanding the life-in-career experiences of women. Weatherhead School of Management: Western Reserve University, 2003.

O'NEIL, D. A.; BILIMORIA, D. Women's career development phases. Idealism, endurance, and reinvention. Career Development International, v. 10, n. 3, p. 168-189, 2005. Available at: https:// doi.org/10.1108/13620430510598300.

PAIVA REIS, V.; MAIA, A. B. P.; BEZERRA, A. R.; CASTEX, D. The new normal of dentistry: review of recommendations for the resumption of dental care during the COVID-19 pandemic. Revista Brasileira de Odontologia, v. 77, n. 1, p. 1-9, 2020. Available at: http://dx.doi.org/10.18363/rbo. v77.2020.e1853.

PIMENTA, D. Pandemia é coisa de mulher: breve ensaio sobre o enfrentamento de uma doença a partir das vozes e silenciamentos femininos dentro das casas, hospitais e na produção acadêmica. Tessituras, v. 8, n. 1, p. 8-19, 2020. Available at: https://doi.org/10.15210/tes.v8i0.18900.

RETTBERG, A. Violencia en América Latina hoy: manifestaciones e impactos. Revista de Estudios Sociales, n. 73, p. 2-17, 2020. Available at: https://doi.org/10.7440/res73.2020.01.

SANTOS, M. P. A.; NERY, J. S.; GOES, E. F.; SILVA, A.; SANTOS, A. B. S.; BATISTA, L. E.; ARAÚJO, E. M. Black population and Covid-19: reflections on racism and health. Estudos Avançados, v. 34, n. 99, p. 225-244, 2020. Available at: https://dx.doi.org/10.1590/s0103-4014.2020.3499.014.

SCANFONE, L.; CARVALHO NETO, A. M.; TANURE, B. Working time and non-working time: the hard balance for the high executive between careers, affective relations and leisure. Revista de Administração FACES Journal, v. 7, n. 1, p. 45-61, 2008. Available at: https://www.redalyc.org/ articulo.oa?id=194016882004.

SCHIEMAN, S.; PHILIP, J. B.; MILKIE, M. A.; BIERMAN, A. Work-Life conflict during the COVID-19 pandemic. Socius, January 2021. Available at: https://doi.org/10.1177/2378023120982856.

SERAFIM, M. C.; BENDASSOLLI, P. F. Carreiras anticoncepcionais. GV-executivo, v. 5, n. 2, p. 62-66, 2006.

SINGH, P.; PATTANAIK, F. Unfolding unpaid domestic work in India: women's constraints, choices, and career. Palgrave Communications, v. 6, n. 111, p. 1-13, 2020. Available at: https:// doi.org/10.1057/s41599-020-0488-2.

SON, C.; HEGDE, S.; SMITH, A.; WANG, X.; SASANGOHAR, F. Effects of COVID-19 on college students' mental health in the United States: interview survey study. Journal of Medical Internet Research, v. 22, n. 9, e21279, Sep. 2020. Available at: https://doi.org/10.2196/21279. 
STANISCUASKI, F. et al. Gender, race and parenthood impact academic productivity during the COVID-19 pandemic: from survey to action. BioRxiv, 4 Jul. 2020. Available at: https://doi. org/10.1101/2020.07.04.187583.

TENENHAUS, M.; VINCI, V. E.; CHATELIN, Y. M.; LAURO, C. PLS path modeling. Computational Statistics and Data Analysis, v. 48, n. 1, p. 159-205, 2005. Available at: https://doi.org/10.1016/ j.csda.2004.03.005.

UNDURRAGA, R.; HORNICKEL, N. L. (Des)articuladas por el cuidado: trayectorias laborales de mujeres chilenas. Revista de Estudios Sociales, n. 75, p. 1-16, 2021. Available at: https://doi. org/10.7440/res75.2021.06.

VALENZUELA, M. E.; SCURO, V.-T. Desigualdad, crisis de los cuidados y migración del trabajo doméstico remunerado en América Latina. Santiago de Chile: Comisión Económica para América Latina y el Caribe (Cepal), 2020. (Série Asuntos de Género, 158). Available at: https://www. cepal.org/es/publicaciones/46537-desigualdad-crisis-cuidados-migracion-trabajo-domesticoremunerado-america.

VIEIRA, A.; AMARAL, G. A. The art of being hummingbird in the woman's triple workday. Saúde e Sociedade, v. 22, n. 2, p. 403-414, 2013. Available at: https://doi.org/10.1590/S010412902013000200012.

VIEIRA, P. R.; GARCIA, L. P.; MACIEL, E. L. N. The increase in domestic violence during the social isolation: what does it reveals? Revista Brasileira de Epidemiologia, v. 23, e200033, 2020. Available at: http://dx.doi.org/10.1590/1980-549720200033.

VINUTO, J. A amostragem em bola de neve na pesquisa qualitativa: um debate em aberto. Temáticas, v. 22, n. 44, p. 203-220, 2014. Available at: https://doi.org/10.20396/tematicas. v22i44.10977.

WANG, C. et al. Respostas psicológicas imediatas e fatores associados durante o estágio inicial da epidemia de doença por coronavírus (Covid-19) de 2019 entre a população em geral na China. International Journal of Environmental Research Public Health, n. 17, e1729, 2020. Available at: https://doi.org/10.3390/ijerph18063232.

WEISS, N.A. Introductory Statistics. 10 th ed. Pearson, 2016.

WOLFF, C. S.; MINELLA, L. S.; LAGO, M. C. S.; RAMOS, T. R. O. Pandemic in neoliberal necroeconomy. Revista Estudos Feministas, v. 28, n. 2, e74311, 2020. Available at: https://dx.doi. org/10.1590/1806-9584-2020v28n274311.

\section{About the authors}

Cláudia Aparecida Avelar Ferreira has doctorate degree in administration for Pontifical Catholic University of Minas Gerais. Postdoctoral internship in Geography - Treatment of spatial information. Researcher at GEDI - Group of Management, Diversity and Inclusion Studies and NIS - Social Intelligence Center

Camila Álvares dos Reis has master's in administration for Pontifical Catholic University of Minas Gerais. Researcher at the NUPEGS Research Group - Research Center on Ethics and Social Management. 


\title{
Contact address
}

\author{
Cláudia Aparecida Avelar Ferreira \\ Av. Itaú, 525, Coração Eucarístico \\ 30535-012 - Belo Horizonte-MG, Brazil \\ Camila Álvares dos Reis \\ Av. Itaú, 525, Coração Eucarístico \\ 30535-012 - Belo Horizonte-MG, Brazil
}

\section{Resumo}

Impacto da Covid-19 nas mulheres brasileiras em teletrabalho

A pandemia de Covid-19 teve impactos nas rotinas pessoal, profissional e acadêmica das teletrabalhadoras brasileiras. Este estudo tem como objetivo analisar o impacto do teletrabalho na vida das mulheres brasileiras em meio à pandemia. 0 método foi uma abordagem quantitativa e exploratória, a partir de uma pesquisa transversal on-line com 478 mulheres. Os resultados mostram que houve correlação positiva entre as rotinas acadêmicas e o teletrabalho ( $p<0,05$; $r>0)$ e associação significativa entre saúde emocional e rotinas acadêmicas separadamente ( $p<0,001)$, sendo que as mulheres negras foram mais esforçadas para as atividades acadêmicas do que as brancas ( $p<0,044)$. Os resultados do estudo contribuem para as ciências sociais, no sentido de demonstrar o impacto da Covid-19 nas mulheres brasileiras no teletrabalho, apontando potenciais consequências para a formulação de políticas e a gestão pública no Brasil.

Palavras chave: Teletrabalho. Tripla jornada. Rotinas pessoal, acadêmica e profissional.

\section{Resumen}

Impacto del COVID-19 en las mujeres brasileñas en el teletrabajo

La pandemia de COVID-19 tuvo impactos en las rutinas personales, profesionales y académicas de las trabajadoras brasileñas. Este estudio tiene como objetivo analizar el impacto del teletrabajo en la vida de las mujeres brasileñas en medio de la pandemia. El método utilizado es un enfoque cuantitativo y exploratorio, además de una encuesta transversal en línea que se aplicó a 478 mujeres. Los resultados mostraron que había una correlación positiva entre las rutinas académicas y el teletrabajo ( $p<0,05 ; r>0)$ y una asociación significativa entre la salud emocional y las rutinas académicas por separado $(p<0,001)$ y las mujeres negras eran más esfuerzos para las actividades académicas que las mujeres blancas $(p<0,044)$. Los resultados del estudio contribuyen a las ciencias sociales al demostrar el impacto de la COVID-19 en las mujeres brasileñas en el teletrabajo, y señala las posibles consecuencias para la formulación de políticas y la gestión pública en Brasil.

Palabras clave: Teletrabajo. Rutinas personales, académicas y profesionales.

Received for publication in $21 / 03 / 2021$

Approved for publication in $12 / 10 / 2021$ 